\title{
Induction of myosin light chain kinase and CPI-17 by TGF- $\beta$ accelerates contractile activity in intestinal epithelial cells
}

\author{
Md. Shafiqul ISLAM ${ }^{1}$, , Noriyuki KAJI'), Shoma MIKAWA ${ }^{1)}$, Qunhui YANG ${ }^{1)}$, \\ Moriaki KUSABE ${ }^{2)}$, Masatoshi HORI') and Hiroshi OZAKI ${ }^{1) *}$ \\ 1)Department of Veterinary Pharmacology, Graduate School of Agriculture and Life Sciences, \\ The University of Tokyo, Tokyo 113-8657, Japan \\ ${ }^{2)}$ Development of Advanced Technology Laboratory Research Center for Food Safety, \\ The University of Tokyo, Tokyo 113-8657, Japan
}

\section{J. Vet. Med. Sci.}

80(6): 977-984, 2018

doi: 10.1292/jvms.17-0684

Received: 28 January 2018

Accepted: 12 April 2018

Published online in J-STAGE:

24 April 2018

\begin{abstract}
Epithelial-mesenchymal transition (EMT) is an orchestral and functional change in epithelial cells. Many signaling pathways are involved in EMT, and transforming growth factor-beta (TGF- $\beta$ ) is considered to be one of the most important factors in induction of EMT. In this study, we treated the rat intestinal epithelial cell line (IEC-6) with TGF- $\beta 1$ as a signaling stimulant. Gross analysis of IEC- 6 cells showed typical characteristics of epithelial cells such as cuboidal morphology and cell-cell contact, whereas treatment with TGF- $\beta 1\left(10 \mathrm{ng} / \mathrm{m}^{-1}\right)$ for 7 days produced robust, spindle-shaped morphology. Immunocytochemistry analysis showed distinct E-cadherin staining in IEC-6 cells, but weak and faint in EMT cells. EMT cells showed positive expression of a-SMA and tenascin-C but IEC- 6 cells did not. Quantitative real-time PCR analysis showed that myosin light chain kinase and C-kinase potentiated protein phosphatase-1 inhibitor (CPI-17) mRNAs were significantly upregulated in EMT cells. Immunocytochemistry analysis also showed that EMT cells strongly expressed CPI-17 but IEC-6 cells did not. A collagen gel contraction assay revealed that EMT cells had greatly increased contraction compared with control cells. These results suggest that the increased contractile activity induced by TGF- $\beta$ in EMT cells may be attributable to the upregulation of molecules responsible for myosin phosphorylation/dephosphorylation.

KEY WORDS: contraction, CPI-17, EMT, MLCK, TGF- $\beta 1$
\end{abstract}

During development as well as in pathological situations such as cancer progression, epithelial cells change to mesenchymal-like cells via different signaling pathways such as pathways mediated by transforming growth factor-beta (TGF- $\beta$ ), fibroblast growth factor, epidermal growth factor, hepatocyte growth factor, Wnt/ $\beta$-catenin, notch, etc. [28]. Among these pathways, TGF- $\beta$ is considered the most important pathway $[12,30,32]$. The TGF- $\beta$ signaling pathway involves many cellular processes that control cell growth, cell differentiation, apoptosis, cellular homeostasis, and other cellular functions. TGF- $\beta$ signal transduction decreases the expression of E-cadherin [27] and increases mesenchymal markers such as fibronectin and $\alpha$-smooth muscle actin ( $\alpha-$ SMA) [18].

Epithelial-mesenchymal transition (EMT) is a cell differentiation process involving an orchestrated series of events in which cell-cell interactions are altered. EMT cells acquire many distinct functions including the appearance of specialized cellular components, some of which are known and others that are not. Although the reason why epithelial cells transform to transitional mesenchyme-like cells is unknown, it is thought to occur during development, wound healing, fibrosis, and metastasis for cancer progression [29].

Contraction is an important cellular function that is involved in many pathophysiological and normal processes such as wound closure $[3,5]$. The contractile patterns of smooth muscle cells and other smooth muscle-like cells such as myofibroblasts vary from cell to cell and tissue to tissue. The role of $\alpha-$ SMA in contraction of EMT cells remains unknown [2, 22]. The physiological importance of TGF- $\beta$ induction of EMT cells and increased contraction remains to be determined. Collagen gel contraction assay revealed that epithelial cells converted to EMT acquired cell contractility [31]; however, there is no established signaling pathways how the EMT cells exhibit increased contraction.

CPI-17 is an endogenous inhibitor protein for myosin light chain phosphatase (MLCP) which plays critical role in smooth muscle contraction. Up regulation and downregulation of CPI-17 occur in pathological conditions resulting in alter contraction

*Correspondence to: Ozaki, H.: aozaki@mail.ecc.u-tokyo.ac.jp

(c2018 The Japanese Society of Veterinary Science

This is an open-access article distributed under the terms of the Creative Commons Attribution Non-Commercial No Derivatives (by-nc-nd) License. (CC-BY-NC-ND 4.0: https://creativecommons.org/licenses/by-nc-nd/4.0/) 
of smooth muscle [13]. Downregulation of CPI-17 may play a role in motility impairments in inflammation [20]. For examples, ulcerative colitis and inflammatory bowel disease (IBD) patients express decreased level of CPI-17 protein, inhibition of myosin light chain phosphorylation and contraction $[19,21]$. On the other hand, increased expression of CPI-17 in smooth muscle and increased phosphorylation of CPI-17 are associated with the increased contraction of vascular smooth muscle contractility and increases blood pressure [25]. Therefore, alteration of CPI-17 regulation in EMT cells could be involved with the cell contraction phenomenon. Recently, we have reported that AOM-DSS-induced chronic colitis model mice have EMT cells [8]. We assumed that chronic consistent inflammation may be involved in the EMT process along with the signaling pathways responsible for possible changes in smooth muscle contractile elements. In the present study, we performed in vitro analysis of EMT and analyzed components of the signaling pathways that may play a role in contraction.

\section{MATERIALS AND METHODS}

\section{Cell culture}

The rat small intestinal cell line, IEC-6, was obtained from RIKEN Cell Bank (RCB0993, Japan). The cells were cultured in Dulbecco's modified Eagle medium (DMEM) containing 10\% fetal bovine serum (FBS). The condition of the cells was observed with a phase contrast microscope, and if the cells were healthy, they were sub-cultured and experiments were performed. In all cases, the experiments were done at least in triplicate.

\section{Immunocytochemistry}

For E-cadherin, $\alpha$-SMA, tenascin-C, and CPI-17 immunocytochemistry, IEC-6 cells were cultured in DMEM containing $10 \%$ FBS on 25-mm cover glass until they reached 50-55\% confluence. When the cultured cells reached 50-55\% confluence, medium was replaced with DMEM supplemented with $0.5 \%$ FBS containing TGF- $\beta 1\left(10 \mathrm{ng} / \mathrm{m} l^{-1}\right)$ for 7 days to induce EMT cells. The cell morphology was observed every day with an inverted microscope. The medium was changed every 2 days. The cells were washed three times with HBSS and fixed with $10 \%$ neutral formalin. After preservation, the cells were washed three times with PBS, permeabilized with Tween 20 (Calbiochem, Darmstadt, Germany), and incubated with blocking buffer containing 5\% normal goat serum for $1 \mathrm{hr}$. Cells were then washed and incubated with purified mouse anti-E-cadherin (1:250) (BD Biosciences, Catalog no. 61081), mouse monoclonal anti- $\alpha$-SMA (1:250) (Santa Cruz Biotechnology, Catalog no. sc-32251), rabbit polyclonal $\alpha-h$ tenascin-C (1:250), or goat polyclonal anti-CPI-17 (1:250) (Santa Cruz Biotechnology) antibody overnight at $4^{\circ} \mathrm{C}$. The specimens were washed and incubated with the appropriate secondary antibodies $(1: 1,000)$ for $2 \mathrm{hr}$ at room temperature in a dark chamber. Nuclei were stained with DAPI (Molecular Probes). Images were obtained using an Eclipse E800 fluorescence microscope (Nikon, Tokyo, Japan).

\section{$R N A$ extraction and RT-PCR analysis}

IEC-6 cells were cultured in DMEM containing 10\% FBS until they reached 50-55\% confluence. When the cultured cells reached 50-55\% confluence, medium was replaced with DMEM supplemented with $0.5 \% \mathrm{FBS}$ containing TGF- $\beta 1\left(10 \mathrm{ng} / \mathrm{m} l^{-1}\right)$ for 7 days to induce EMT cells. The medium was changed every 2 days. Total RNA was extracted by using Trizol reagent (Invitrogen, Tokyo, Japan). First-strand cDNA was synthesized by using a random nine-mer primer and ReverTra Ace ${ }^{(\mathrm{R})}$ (a high efficient M-MLV; Moloney Murine Leukemia Virus reverse transcriptase) (Toyobo, Tokyo Japan) at $30^{\circ} \mathrm{C}$ for $10 \mathrm{~min}, 42^{\circ} \mathrm{C}$ for $1 \mathrm{hr}, 99^{\circ} \mathrm{C}$ for $5 \mathrm{~min}$, and $4^{\circ} \mathrm{C}$ for $5 \mathrm{~min}$. PCR amplification was performed by using ExTaq DNA polymerase. Primers used for PCR analysis are shown in Table 1. After an initial check, we selected 32 cycles for $\alpha$-SMA, E-cadherin, and tenascin-C.

\section{Quantitative real-time PCR analysis}

Real-time PCR was performed in an AriaMx Real-Time PCR System (Agilent Technologies, Santa Clara, CA, U.S.A.) using SYBR-green fluorescence (Thunderbird ${ }^{\mathrm{TM}} \mathrm{SYBR}^{\circledR}$, Toyobo, Japan) with the ROX reference dye [8]. Primers used for real-time PCR analysis are shown in Table 2. Amplification conditions were $95^{\circ} \mathrm{C}$ for $60 \mathrm{sec}$ as a hot start, followed by 45 cycles of $95^{\circ} \mathrm{C}$ for $15 \mathrm{sec}$ and $60^{\circ} \mathrm{C}$ for $60 \mathrm{sec}$. High-resolution dissociation (melting) curves were calculated following reaction at $95^{\circ} \mathrm{C}$ for $30 \mathrm{sec}$ and $60-95^{\circ} \mathrm{C}$ for $30 \mathrm{sec}$ to confirm primer specificity. The purity of the amplified products was confirmed by dissociation curves and gel electrophoresis. Samples were analyzed by the $\Delta \mathrm{Cq}$ method using $18 \mathrm{~S}$ as the reference gene.

\section{Collagen gel contraction analysis of IEC-6 and EMT cells}

A collagen gel contraction assay was used to study the inherent and acquired contractile ability of the cells. A modified collagen gel contraction assay was used in this study [1]. In brief, a collagen lattice was prepared by mixing 70\% type I collagen from porcine tendon (Nitta Gelatin, Japan), 20\% $5 \times$ DMEM and 10\% $0.05 \mathrm{~N} \mathrm{NaOH}$ on ice (collagen concentration, $2.1 \mathrm{mg} / \mathrm{m} l^{-1}$ ). The mixture was then added to each well of 12 -well plates and incubated at $37^{\circ} \mathrm{C}$ for $1 \mathrm{hr}$. After solidification, IEC- 6 cells or EMT cells were seeded on the top of the lattice at a density of $1 \times 10^{5}$ cells in each well and incubated overnight for complete attachment. Under microscopic examination and after observing proper attachment of cells, the cells were incubated in serum-free conditions for $24 \mathrm{hr}$. TGF- $\beta 1\left(10 \mathrm{ng} / \mathrm{m} l^{-1}\right)$ was added to EMT cells in all conditions. For the positive control, 1\% FBS was added 30 min before detachment of the lattice from the well. The lattice was detached from each well with a micro-spatula and photographed at $0,1,2$ and $3 \mathrm{hr}$ with or without treatment. Finally, the lattice area was measured by Image J software (National Institutes of Health, Bethesda, MD, U.S.A.). 
Table 1. Sequences of the primers used for RT-PCR analysis

\begin{tabular}{|c|c|c|c|}
\hline Primer sets & Orientation & Sequence ( $5^{\prime}$ to $\left.3^{\prime}\right)$ & PCR product $(\mathrm{bp})$ \\
\hline \multirow[t]{2}{*}{ Rat- $\alpha$-SMA (NM_031004) } & Forward & GGGAGTGATGGTTGGAATGG & 197 \\
\hline & Reverse & CCGTTAGCAAGGTCGGATG & \\
\hline \multirow[t]{2}{*}{ Rat E-cadherin } & Forward & ATCTAAAGCTTCACAAGCTGGA & 502 \\
\hline & Reverse & TGATCTGTGACTGTGACCACTA & \\
\hline \multirow[t]{2}{*}{ Rat-TnC (XM_008763758.2) } & Forward & ATGTTGAATGGCGACAC & 188 \\
\hline & Reverse & CGGTCTCCAAACCCAG & \\
\hline \multirow[t]{2}{*}{ Rat-GAPDH (XM_576394) } & Forward & TCCCTCAAGATTGTCAGCAA & 308 \\
\hline & Reverse & AGATCCACAACGGATACATT & \\
\hline
\end{tabular}

Table 2. All primers used in real-time PCR analysis

\begin{tabular}{|c|c|c|c|}
\hline Primer sets & Orientation & Sequence $\left(5^{\prime}\right.$ to $\left.3^{\prime}\right)$ & PCR product $(\mathrm{bp})$ \\
\hline \multirow[t]{2}{*}{ Rat- CPI-17 (NM_130403) } & Forward & GACGAGCTGCTGGAATTGG & 89 \\
\hline & Reverse & AAGTCCTCTGTGGGATTCAGG & \\
\hline \multirow[t]{2}{*}{ Rat- MLCK (XM_213611) } & Forward & GCTGCACAGCATCCAATACC & 153 \\
\hline & Reverse & CAGAGCACCGTAGCACAAAATC & \\
\hline \multirow[t]{2}{*}{ Rat- MYPT1 (NM_053890) } & Forward & GTCAGCTCAACAGGCCAAAC & 128 \\
\hline & Reverse & AGGTTGTGACTTATCTTCCCCTTC & \\
\hline \multirow[t]{2}{*}{ Rat- RhoA (NM_057132) } & Forward & AGCACACAAGGCGGGAGTTAG & 108 \\
\hline & Reverse & CTGAACACTCCATGTACCCAAAAG & \\
\hline \multirow[t]{2}{*}{ Rat- ROCK1 (NM_031098) } & Forward & AGATGCCATGTTAAGTCCCACA & 194 \\
\hline & Reverse & GCACGGACAAAGCCAGAAG & \\
\hline \multirow[t]{2}{*}{ Rat- ROCK2 (NM_013022) } & Forward & TCAGAGGTTTACAGATGAAAGCAGA & 98 \\
\hline & Reverse & TGATGCCTTATGACGAACCAAC & \\
\hline \multirow[t]{2}{*}{ 18S rRNA } & Forward & AAACGGCTACCACATCCAAG & 155 \\
\hline & Reverse & CCTCCAATGGATCCTCGTTA & \\
\hline
\end{tabular}

\section{Western blotting analysis for conditioned medium and cell lysates of IEC-6 cells and EMT cells}

Conditioned medium and cell lysates were used for Western blot analysis [9]. Cell lysates were prepared in extraction buffer containing $150 \mathrm{mM} \mathrm{NaCl}, 1 \% \mathrm{NP}-40,0.5 \%$ DOC, $0.1 \%$ SDS, $50 \mathrm{mM}$ Tris-HCl, pH 7.5, $20 \mathrm{mM}$ EDTA, complete protease inhibitor (Roche) and Pefabloc SC (Roche). Samples were prepared with $5 \mu \mathrm{g}$ of protein (cell lysates and conditioned media) mixed with 6x SDS-sample buffer under reducing conditions. Samples were boiled at $100^{\circ} \mathrm{C}$ for $5 \mathrm{~min}$ and then subjected to $5 \%$ SDS-PAGE. Membranes were blocked in PBS containing 5\% normal goat serum and $1 \%$ bovine serum albumin. The membranes were incubated with $\alpha$-hTnC polyclonal antibody (1:500) and rabbit $\alpha$ - $\beta$-actin polyclonal antibody (1:500). After washing, the membranes were incubated with the appropriate HRP-conjugated secondary antibody.

\section{Data and statistical analysis}

Results are expressed as the mean \pm SEM. Statistical analysis of the data was performed using GraphPad Prism 3 (GraphPad Software, La Jolla, CA, U.S.A.). The Student's unpaired $t$-test was used to compare two groups, whereas one-way ANOVA with a Bonferroni post-hoc test was used to compare more than two groups. $P<0.05$ and $P<0.01$ were considered statistically significant.

\section{RESULTS}

\section{TGF- $\beta 1$ induced EMT cells from IEC-6 epithelial cells}

Treatment of IEC-6 epithelial cells with TGF- $\beta 1\left(10 \mathrm{ng} / \mathrm{m} l^{-1}\right)$ for 7 days resulted in a change in morphology to robust, spindleshaped mesenchymal-like cells. Untreated epithelial cells showed characteristics such as cuboidal-shaped morphology and cell-cell contact (Fig. 1A, panels a-b). Immunocytochemistry analysis of TGF- $\beta 1$-treated cells demonstrated loss of the epithelial cell marker E-cadherin and gain of the mesenchymal cell marker $\alpha$-SMA. Untreated IEC- 6 cells clearly expressed E-cadherin but not $\alpha$-SMA (Fig. 1B, panels a-b and 1C, panels a-b). Molecular analysis with RT-PCR further confirmed that EMT cells expressed significantly $(P<0.05)$ upregulated levels of $\alpha$-SMA mRNA. E-cadherin mRNA was expressed at lower levels than in control cells, although the difference was not significant (Fig. 1D).

\section{TGF- $\beta 1$ induced expression of tenascin-C in EMT cells}

Tenascin-C is an extracellular matrix glycoprotein that is expressed at high levels during embryogenesis but is almost absent during normal postnatal life [11]. Recently, we showed that tenascin-C is a very good marker for mesenchymal cells [9]. Thus, we 


\section{A Phase contrast}

(a) Control

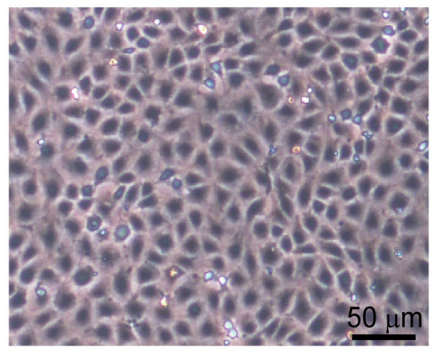

B E-cadherin

(a) Control

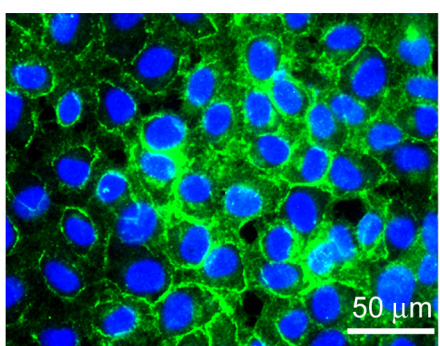

E-cadherin (b) +TGF $\beta 110 \mathrm{ng}$ (7 days)

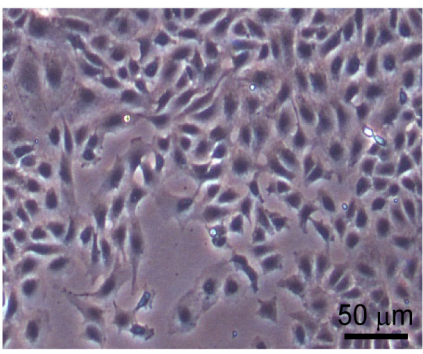

(b) +TGF $\beta 110$ ng (7 days)

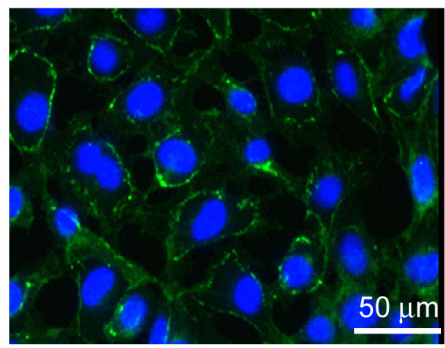

E-cadherin

\section{RT-PCR}
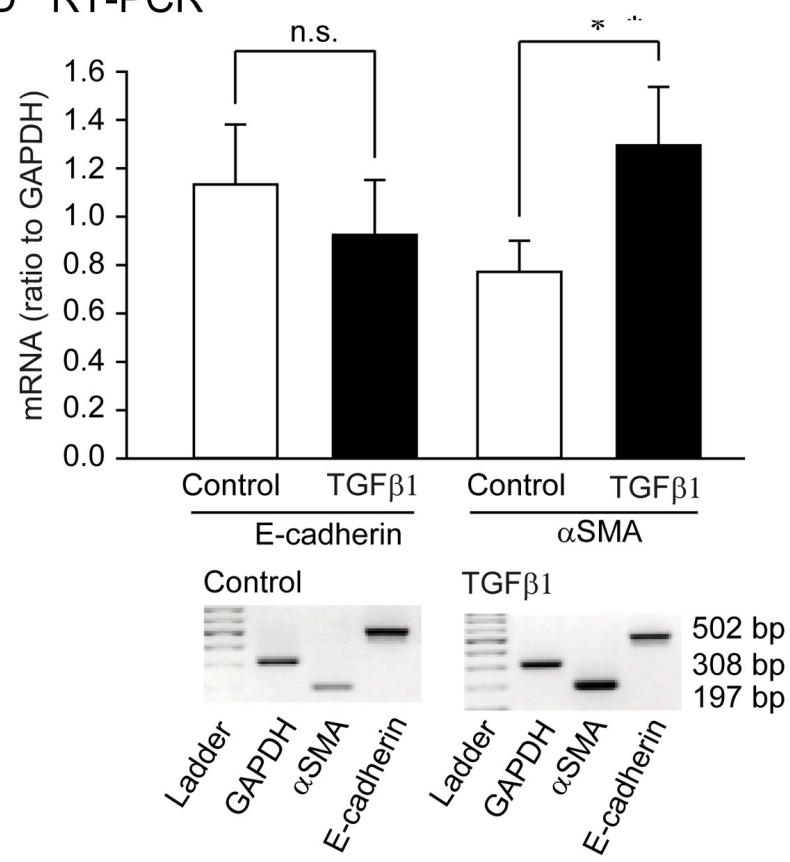

\section{C $\alpha$ SMA}

(a) Control

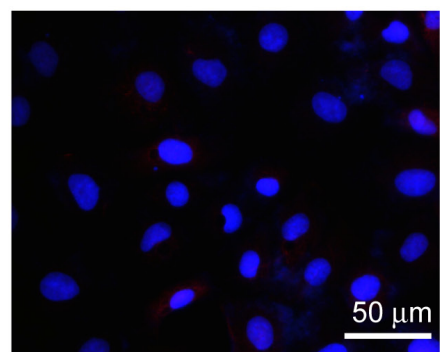

(b) +TGF $\beta 110$ (7 days)

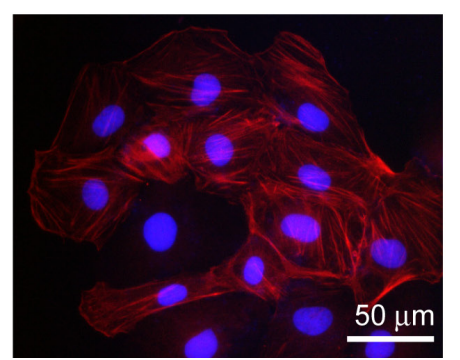

Fig. 1. TGF- $\beta 1$ induced EMT in IEC-6 cells. IEC-6 cells were cultured in DMEM with or without TGF- $\beta 1\left(10 \mathrm{ng} / \mathrm{m} l^{-1}\right)$ for 7 days. (A) Phase contrast photograph; (a) morphology of epithelial cells showing a cuboidal shape and cell-cell contact in control cells, (b) spindle-shaped morphology of EMT cells. (B) Immunocytochemistry analysis of E-cadherin; (a) control cells prominently expressed E-cadherin (green color, E-cadherin; blue color, nucleus), (b) EMT cells lost E-cadherin expression (green color, E-cadherin; blue color, nucleus). (C) Immunocytochemistry analysis of $\alpha$-SMA; (a) control cells did not express $\alpha$-SMA (red color, $\alpha$-SMA; blue color, nucleus), (b) many EMT cells were $\alpha$-SMA positive (red color, $\alpha$-SMA; blue color, nucleus). $\mathrm{n}=5$. Bar $=50 \mu \mathrm{m}$. (D) RT-PCR analysis of E-cadherin and $\alpha$-SMA; EMT cells expressed significantly higher levels of $\alpha$-SMA and markedly lower levels of E-cadherin mRNA. $\mathrm{n}=5, * P<0.05$.

investigated tenascin-C expression in TGF- $\beta 1$-induced EMT cells. Immunocytochemistry showed that TGF- $\beta 1$-treated EMT cells expressed high levels of tenascin-C, whereas control epithelial cells were not immuno-positive for tenascin-C (Fig. 2A, panels a-b). RT-PCR analysis revealed that EMT cells significantly $(P<0.05)$ upregulated tenascin-C mRNA compared to control cells $($ Fig. $2 \mathrm{~B})$. Western blot analysis further confirmed that EMT cells significantly $(P<0.01)$ upregulated tenascin-C and secreted the molecule into the medium (Fig. 2C, panels a-b). In control cells, tenascin-C was nearly undetectable in both conditioned medium and cell lysates (Fig. 2C, panels a-b).

TGF- $\beta 1$ induced expression of myosin light chain kinase (MLCK) and CPI-17 in EMT cells

We next examined the change in smooth muscle contractile elements after treatment with TGF- $\beta 1$. Quantitative real-time PCR analysis showed that treatment with TGF- $\beta 1$ resulted in significant upregulation of MLCK $(P<0.05)$ and CPI-17 $(P<0.01)$ mRNA in EMT cells compared to the control IEC-6 cells (Fig. 3A). No remarkable differences in expression of RhoA, MYPT1, ROCK1, 


\section{IEC-6 Epithelial cell}

\section{A Tenascin-C Immunohistochemistry}
(a) 7 days control

(b) +TGF- $\beta 1$ (7 days)

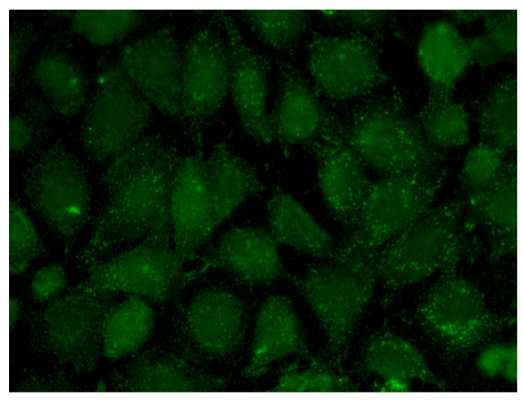

Tenascin-C

\section{Western blot}

(a) Tenascin-C (Conditioned medium)

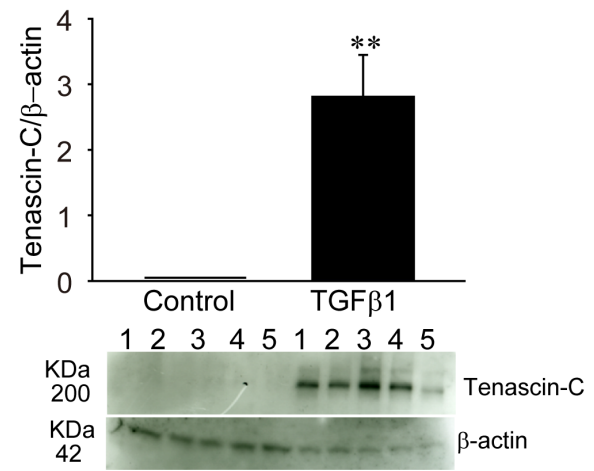

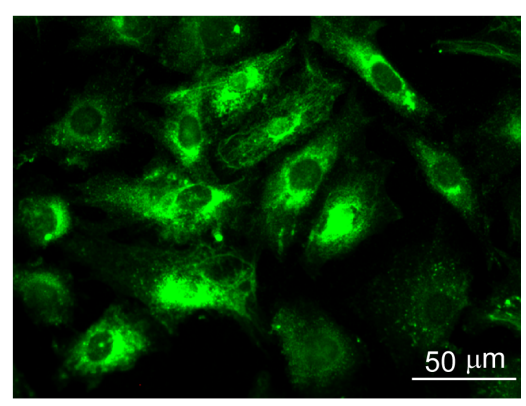

Tenascin-C

(b) Tenascin-C (Cell lysate)

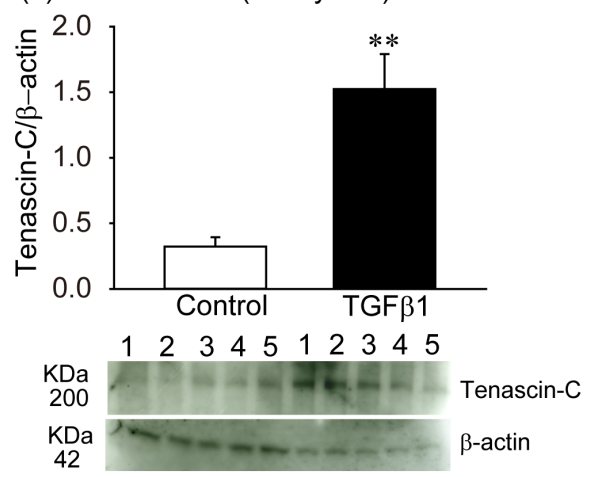

B RT-PCR

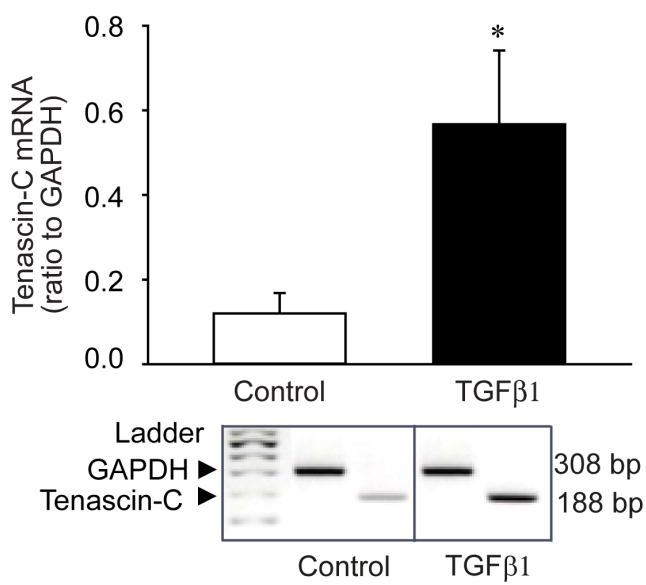

Fig. 2. TGF- $\beta 1$ induced expression of tenascin-C in EMT cells. IEC- 6 cells were cultured in DMEM with or without TGF- $\beta 1\left(10 \mathrm{ng} / \mathrm{m} l^{-1}\right)$ for 7 days. (A) Immunocytochemical analysis of tenascin-C; (a) control cells did not express tenascin-C (green color, tenascin-C); (b) EMT cells expressed high levels of tenascin-C. $\mathrm{n}=5$. Bar $=50 \mu \mathrm{m}$. (B) RT-PCR analysis of tenascin-C mRNA; EMT cells expressed significantly increased levels of tenascin-C mRNA. $\mathrm{n}=5,{ }^{*} P<0.05$. (C) Western blot analysis of conditioned medium and cell lysates; (a) EMT cells excreted significantly higher levels of tenascin-C into the medium compared to controls cells, which did not excrete detectable levels of tenascin-C into the medium, (b) significantly higher levels of tenascin-C were found in cell lysates of EMT cells compared to control cell lysates, which showed a negligible quantity of tenascin-C. $\mathrm{n}=5, * * P<0.01$.

or ROCK2 were observed between control and EMT cells (Fig. 3A). Immunocytochemistry analysis further confirmed that EMT cells strongly expressed CPI-17 but IEC-6 epithelial cells did not (Fig. 3B, panels a-b).

\section{TGF- $\beta 1$ induced increased collagen gel contraction by EMT cells}

MLCK inherently controls contraction through signaling pathways via myosin phosphorylation. CPI-17 differentially controls phosphorylation levels through inhibition of myosin light chain phosphatase activity [14]. Therefore, we next examined the potency of collagen gel contraction by EMT and control IEC-6 cells. We found that EMT cells treated with or without $1 \%$ FBS showed significantly $(P<0.01)$ increased collagen gel contraction compared with control cells (Fig. 4A and 4B).

\section{DISCUSSION}

EMT cells appear in physiological and pathological conditions. The signaling pathway that induces EMT is complex [17]. Physiologically, EMT is a principal step during embryonic morphogenesis, and pathologically, EMT plays a role in chronic degenerative fibrosis, cancer metastasis, etc. [29]. Many scientists also believe that EMT may be involved in cancer progression due to loss of E-cadherin [26].

EMT cells lose and acquire many new components; some are known and others are unknown. In our study, we used TGF- $\beta 1$ to induce EMT and found that EMT cells acquired a spindle-shaped, mesenchymal-like morphology, lost expression of E-cadherin, and gained expression of $\alpha$-SMA and the extracellular matrix protein, tenascin-C [9, 23]. We also found that EMT cells exhibited high contractile activity in the collagen gel contraction assay compared to control epithelial cells. Although several pathways and cellular components are involved in the contraction mechanism, phosphorylation and de-phosphorylation of the regulatory light chain of myosin via the $\mathrm{Ca}^{2+}$-calmodulin dependent MLCK play critical roles [24]. Additionally, the sensitivity of smooth muscle contractile 


\section{A Real time PCR}

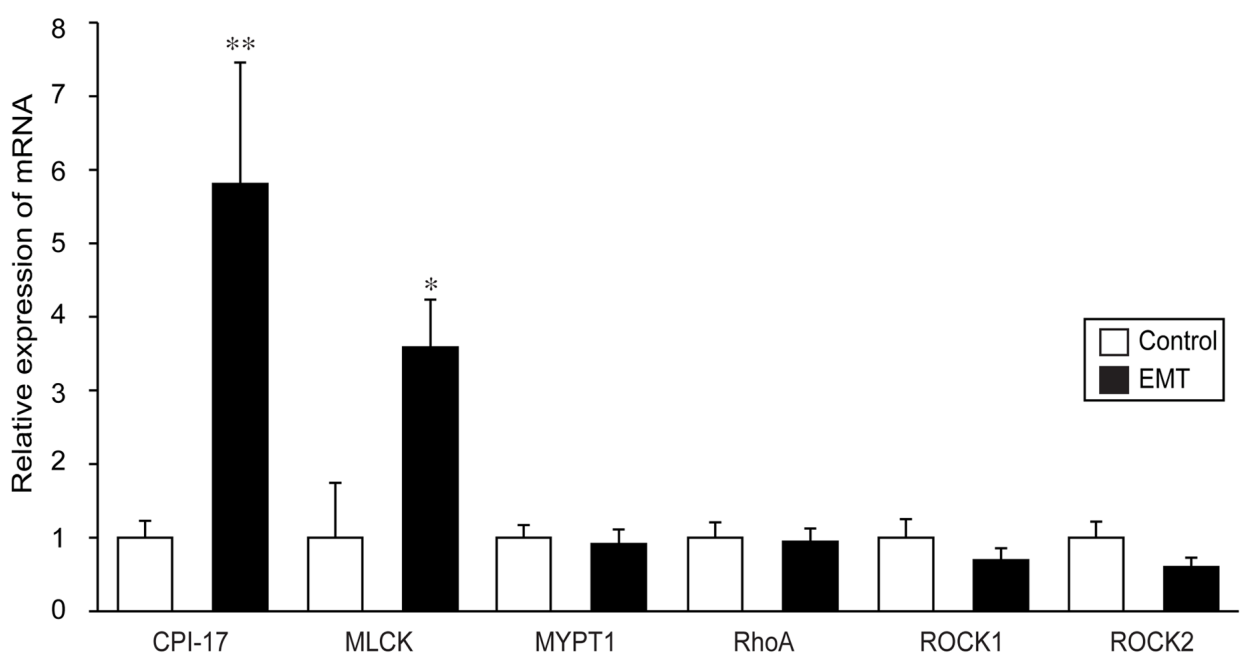

\section{B Immuhistochemistry-CPI17}

(a) Control IEC-6 cells

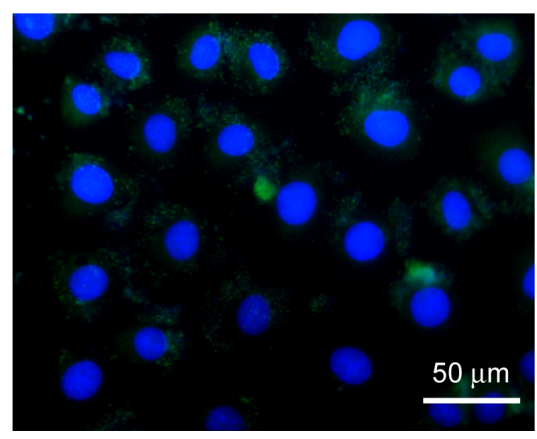

(b) +TGF- $\beta 1$ (7 days)

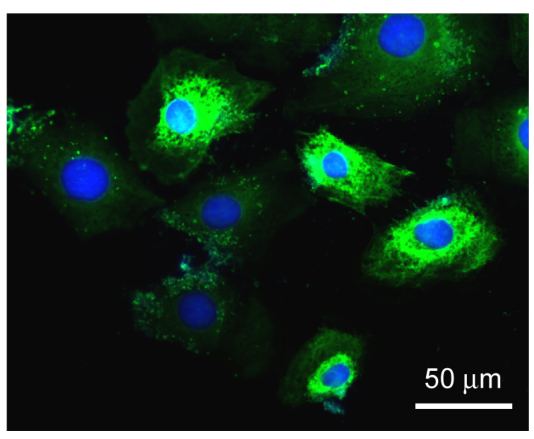

Fig. 3. TGF- $\beta 1$ induced expression of CPI- 17 and MLCK in EMT cells. IEC-6 cells were cultured in DMEM containing TGF- $\beta 1$ $\left(10 \mathrm{ng} / \mathrm{ml}^{-1}\right)$ for 7 days. (A) Quantitative real-time PCR analysis of CPI-17, MLCK, MYPT1, RhoA, ROCK1, and ROCK2 mRNA in control and EMT cells. EMT cells expressed significantly higher levels of CPI-17 and MLCK mRNA. $\mathrm{n}=5, * P<0.05$ and $* * P<0.01$. (B) Immunocytochemistry analysis of CPI-17; (a) control epithelial cells did not express CPI-17 (green color, CPI-17; blue color, nucleus); (b) EMT cells expressed CPI-17 (green color, CPI-17; blue color, nucleus). n=5. Bar=50 $\mu \mathrm{m}$.

elements to cytosolic $\mathrm{Ca}^{2+}$ is greatly dependent on CPI-17, an inhibitor protein of myosin light chain phosphatase [4, 14]. Inhibition of myosin phosphatase is critical for agonist-induced contractility of vascular smooth muscle. In the CPI-17 response to agonists, Thr-38 is phosphorylated by protein kinase C producing an increase in inhibitory potency [7, 15]. Smooth muscle-specific CPI-17 transgenic mouse (CPI-17-Tg) selectively expressed in smooth muscle-enriched tissues including mesenteric arteries and response to norepinephrine was enhanced in CPI-17-Tg mice and the hypercontractility was associated with increased phosphorylation of CPI-17 and 20-kDa myosin light chain under basal and stimulated conditions [25]. CPI-17 is a substrate of Rho-kinase which could be involved in the $\mathrm{Ca}^{2+}$ sensitization of smooth muscle contraction [16], myosin-associated protein phosphatase-1 holoenzyme [6] and contraction [25]. In this study, we found that EMT cells lost E-cadherin expression but gained $\alpha$-SMA, tenascin-C, MLCK and CPI-17 expression; however, mRNA for RhoA, MYPT1, ROCK1 and ROCK2, were unchanged in both normal and EMT cells. Not only smooth muscle cells but also other cells express a small amount of CPI-17, including intestinal epithelial cells, epithelial cells in the lung alveoli, trachea, and esophagus [14], and epithelial-derived tumor cells [10].

In conclusion our results suggest that TGF- $\beta 1$-induced EMT cells showed increased cellular contraction via changes in the MLCK (phosphorylation step) and CPI-17 (de-phosphorylation step) signaling pathway that contributes to the myosin phosphorylation and de-phosphorylation process.

ACKNOWLEDGMENTS. This work was supported by JSPS KAKENHI Grant numbers 25221205 and 24248050. No conflicts of interest, financial or otherwise, are declared by the authors. MIS and HO designed the research; MIS performed experiments; HO, MH, NK, SM, QY and MK discussed the research study; MIS and HO wrote the manuscript. 
A

(a) Control (-)

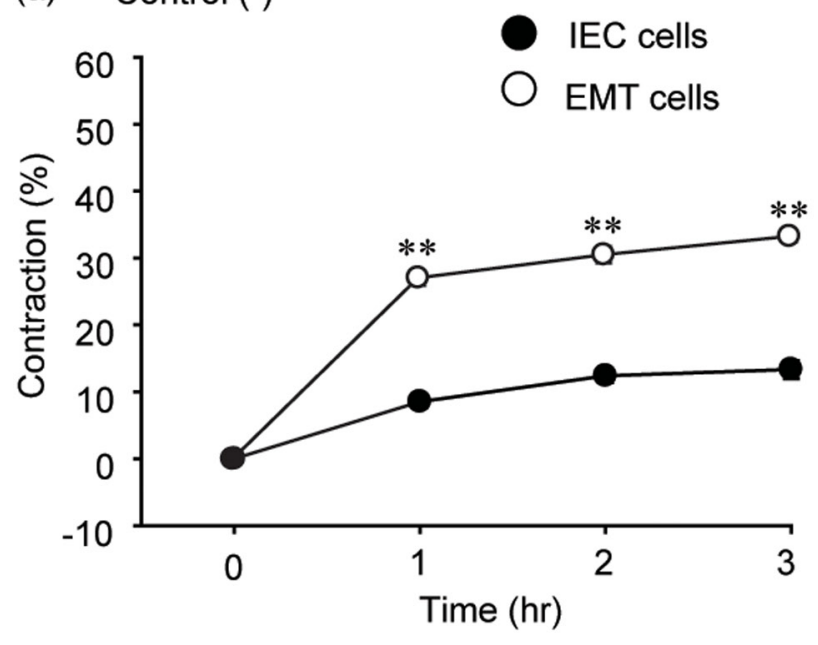

(b)

(i) IEC

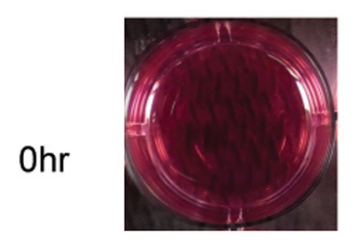

(ii) EMT

$3 \mathrm{hr}$

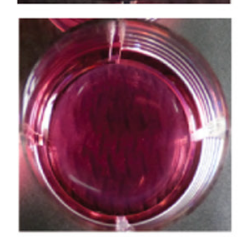

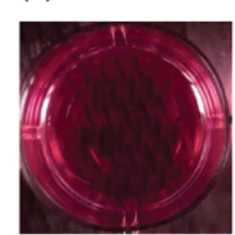

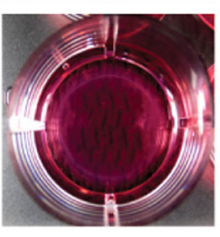

B

(a) Control ( + 1\% FBS)

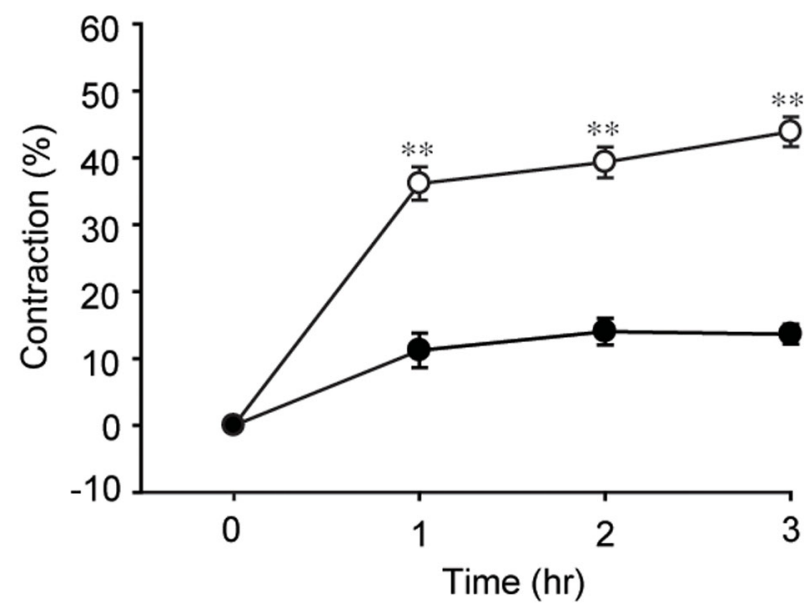

(b)

(i) IEC
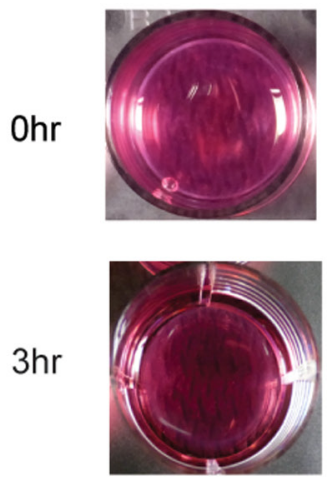

(ii) EMT
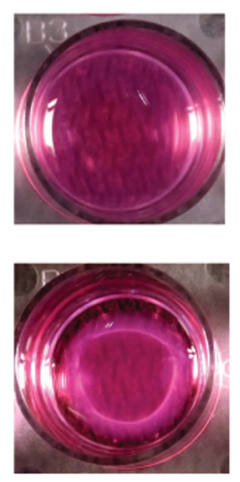

Fig. 4. TGF- $\beta 1$ induced greater collagen gel contraction in EMT cells. IEC-6 cells were cultured in DMEM with or without TGF- $\beta 1\left(10 \mathrm{ng} / \mathrm{m} l^{-1}\right)$ for 7 days. (A) Collagen gel contraction in the absence of FBS; (a) control IEC-6 cells and EMT cells, (b) representative photograph showing the contraction pattern of IEC-6 cells and EMT cells. (B) Collagen gel contraction in presence of 1\% FBS; (a) FBS-treated IEC-6 cells and FBS-treated EMT cells, (b) representative photograph showing the contraction pattern of FBS-treated IEC-6 cells and FBS-treated EMT cells. Collagen gel lattice is considered $100 \%$ at zero level contraction. $\mathrm{n}=5, * * P<0.01$.

\section{REFERENCES}

1. Ayabe, S., Murata, T., Maruyama, T., Hori, M. and Ozaki, H. 2009. Prostaglandin E2 induces contraction of liver myofibroblasts by activating EP3 and FP prostanoid receptors. Br. J. Pharmacol. 156: 835-845. [Medline] [CrossRef]

2. Bedi, S., Vidyasagar, A. and Djamali, A. 2008. Epithelial-to-mesenchymal transition and chronic allograft tubulointerstitial fibrosis. Transplant. Rev. (Orlando) 22: 1-5. [Medline] [CrossRef]

3. Chitturi, R. T., Balasubramaniam, A. M., Parameswar, R. A., Kesavan, G., Haris, K. T. and Mohideen, K. 2015. The role of myofibroblasts in wound healing, contraction and its clinical implications in cleft palate repair. J. Int. Oral Health 7: 75-80. [Medline]

4. Dallon, J. C. and Ehrlich, H. P. 2010. Differences in the mechanism of collagen lattice contraction by myofibroblasts and smooth muscle cells. $J$. Cell. Biochem. 111: 362-369. [Medline] [CrossRef]

5. Diegelmann, R. F. and Evans, M. C. 2004. Wound healing: an overview of acute, fibrotic and delayed healing. Front. Biosci. 9: 283-289. [Medline] [CrossRef]

6. Eto, M., Kirkbride, J. A., Chugh, R., Karikari, N. K. and Kim, J. I. 2013. Nuclear localization of CPI-17, a protein phosphatase-1 inhibitor protein, affects histone $\mathrm{H} 3$ phosphorylation and corresponds to proliferation of cancer and smooth muscle cells. Biochem. Biophys. Res. Commun. 434: 137-142. [Medline] [CrossRef]

7. Eto, M., Kitazawa, T. and Brautigan, D. L. 2004. Phosphoprotein inhibitor CPI-17 specificity depends on allosteric regulation of protein phosphatase-1 by regulatory subunits. Proc. Natl. Acad. Sci. U.S.A. 101: 8888-8893. [Medline] [CrossRef]

8. Islam, M. S., Horiguchi, K., Iino, S., Kaji, N., Mikawa, S., Hori, M. and Ozaki, H. 2016. Epidermal growth factor is a critical regulator of the cytokine IL-33 in intestinal epithelial cells. Br. J. Pharmacol. 173: 2532-2542. [Medline] [CrossRef]

9. Islam, M. S., Kusakabe, M., Horiguchi, K., Iino, S., Nakamura, T., Iwanaga, K., Hashimoto, H., Matsumoto, S., Murata, T., Hori, M. and Ozaki, H. 2014. PDGF and TGF- $\beta$ promote tenascin-C expression in subepithelial myofibroblasts and contribute to intestinal mucosal protection in mice. $B r$. J. Pharmacol. 171: 375-388. [Medline] [CrossRef] 
10. Jin, H., Sperka, T., Herrlich, P. and Morrison, H. 2006. Tumorigenic transformation by CPI-17 through inhibition of a merlin phosphatase. Nature 442: 576-579. [Medline] [CrossRef]

11. Jones, P. L. and Jones, F. S. 2000. Tenascin-C in development and disease: gene regulation and cell function. Matrix Biol. 19: 581-596. [Medline] [CrossRef]

12. Katsuno, Y., Lamouille, S. and Derynck, R. 2013. TGF- $\beta$ signaling and epithelial-mesenchymal transition in cancer progression. Curr. Opin. Oncol. 25: 76-84. [Medline] [CrossRef]

13. Kim, J. I., Urban, M., Young, G. D. and Eto, M. 2012. Reciprocal regulation controlling the expression of CPI-17, a specific inhibitor protein for the myosin light chain phosphatase in vascular smooth muscle cells. Am. J. Physiol. Cell Physiol. 303: C58-C68. [Medline] [CrossRef]

14. Kim, J. I., Young, G. D., Jin, L., Somlyo, A. V. and Eto, M. 2009. Expression of CPI-17 in smooth muscle during embryonic development and in neointimal lesion formation. Histochem. Cell Biol. 132: 191-198. [Medline] [CrossRef]

15. Kitazawa, T., Polzin, A. N. and Eto, M. 2004. CPI-17-deficient smooth muscle of chicken. J. Physiol. 557: 515-528. [Medline] [CrossRef]

16. Koyama, M., Ito, M., Feng, J., Seko, T., Shiraki, K., Takase, K., Hartshorne, D. J. and Nakano, T. 2000. Phosphorylation of CPI-17, an inhibitory phosphoprotein of smooth muscle myosin phosphatase, by Rho-kinase. FEBS Lett. 475: 197-200. [Medline] [CrossRef]

17. Lamouille, S., Xu, J. and Derynck, R. 2014. Molecular mechanisms of epithelial-mesenchymal transition. Nat. Rev. Mol. Cell Biol. 15: 178-196. [Medline] [CrossRef]

18. Miettinen, P. J., Ebner, R., Lopez, A. R. and Derynck, R. 1994. TGF-beta induced transdifferentiation of mammary epithelial cells to mesenchymal cells: involvement of type I receptors. J. Cell Biol. 127: 2021-2036. [Medline] [CrossRef]

19. Ohama, T., Hori, M., Fujisawa, M., Kiyosue, M., Hashimoto, M., Ikenoue, Y., Jinno, Y., Miwa, H., Matsumoto, T., Murata, T. and Ozaki, H. 2008. Downregulation of CPI-17 contributes to dysfunctional motility in chronic intestinal inflammation model mice and ulcerative colitis patients. $J$. Gastroenterol. 43: 858-865. [Medline] [CrossRef]

20. Ohama, T., Hori, M., Momotani, E., Iwakura, Y., Guo, F., Kishi, H., Kobayashi, S. and Ozaki, H. 2007. Intestinal inflammation downregulates smooth muscle CPI-17 through induction of TNF-alpha and causes motility disorders. Am. J. Physiol. Gastrointest. Liver Physiol. 292: G1429G1438. [Medline] [CrossRef]

21. Ohama, T., Hori, M., Sato, K., Ozaki, H. and Karaki, H. 2003. Chronic treatment with interleukin-1 beta attenuates contractions by decreasing the activities of CPI-17 and MYPT-1 in intestinal smooth muscle. J. Biol. Chem. 278: 48794-48804. [Medline] [CrossRef]

22. Oishi, K., Ogawa, Y., Gamoh, S. and Uchida, M. K. 2002. Contractile responses of smooth muscle cells differentiated from rat neural stem cells. $J$. Physiol. 540: 139-152. [Medline] [CrossRef]

23. Song, J. 2007. EMT or apoptosis: a decision for TGF-beta. Cell Res. 17: 289-290. [Medline] [CrossRef]

24. Stull, J. T., Tansey, M. G., Tang, D. C., Word, R. A. and Kamm, K. E. 1993. Phosphorylation of myosin light chain kinase: a cellular mechanism for Ca2+ desensitization. Mol. Cell. Biochem. 127-128: 229-237. [Medline] [CrossRef]

25. Su, W., Xie, Z., Liu, S., Calderon, L. E., Guo, Z. and Gong, M. C. 2013. Smooth muscle-selective CPI-17 expression increases vascular smooth muscle contraction and blood pressure. Am. J. Physiol. Heart Circ. Physiol. 305: H104-H113. [Medline] [CrossRef]

26. Tepass, U., Truong, K., Godt, D., Ikura, M. and Peifer, M. 2000. Cadherins in embryonic and neural morphogenesis. Nat. Rev. Mol. Cell Biol. 1: 91-100. [Medline] [CrossRef]

27. Vogelmann, R., Nguyen-Tat, M. D., Giehl, K., Adler, G., Wedlich, D. and Menke, A. 2005. TGFbeta-induced downregulation of E-cadherin-based cell-cell adhesion depends on PI3-kinase and PTEN. J. Cell Sci. 118: 4901-4912. [Medline] [CrossRef]

28. Wang, Y. and Zhou, B. P. 2011. Epithelial-mesenchymal transition in breast cancer progression and metastasis. Chin. J. Cancer 30: 603-611. [Medline] [CrossRef]

29. Wu, Y. and Zhou, B. P. 2008. New insights of epithelial-mesenchymal transition in cancer metastasis. Acta Biochim. Biophys. Sin. (Shanghai) 40: 643-650. [Medline] [CrossRef]

30. Xu, J., Lamouille, S. and Derynck, R. 2009. TGF-beta-induced epithelial to mesenchymal transition. Cell Res. 19: 156-172. [Medline] [CrossRef]

31. Yamauchi, Y., Kohyama, T., Takizawa, H., Kamitani, S., Desaki, M., Takami, K., Kawasaki, S., Kato, J. and Nagase, T. 2010. Tumor necrosis factor-alpha enhances both epithelial-mesenchymal transition and cell contraction induced in A549 human alveolar epithelial cells by transforming growth factor-beta1. Exp. Lung Res. 36: 12-24. [Medline] [CrossRef]

32. Yue, J. and Mulder, K. M. 2001. Transforming growth factor-beta signal transduction in epithelial cells. Pharmacol. Ther. 91: 1-34. [Medline] [CrossRef] 